\title{
Karl Schmückle and Western Marxism
}

\section{Kaan Kangal}

To cite this article: Kaan Kangal (2018) Karl Schmückle and Western Marxism, Revolutionary Russia, 31:1, 67-85, DOI: 10.1080/09546545.2018.1478671

To link to this article: https://doi.org/10.1080/09546545.2018.1478671

央 Published online: 18 Jun 2018.

Submit your article to this journal

Џ Article views: 48

View Crossmark data $\asymp$ 


\title{
Kaan Kangal
}

\section{KARL SCHMÜCKLE AND WESTERN MARXISM}

\begin{abstract}
Born in 1898 in South-West Germany, the son of a lumberjack, a student of Karl Korsch in Jena, a colleague of Georg Lukács in Moscow, a militant of the Communist Part of Germany (KPD), and later a member of the All-Union Communist Party of Bolsheviks (VKPB), Schmückle was a prominent Marx expert, a literary critic and an editor of the first MarxEngels-Gesamtausgabe (MEGA1). This article examines whether Schmückle can be called a Western Marxist. To this end, it first investigates the theoretic, geological and social patterns of Western Marxism and then detects similarities and differences between Schmückle and some pioneering figures of Western Marxism. My main contention is that Western Marxist historiography potentially excludes much of what stands and falls with Schmückle's intellectual biography and political identity. The way Western Marxism would read Schmückle leads to the conclusion that Schmückle was a Westerner and a Marxist, but hardly a Western Marxist. This suggests that either Western Marxism applies to him in a very loose sense or, alternatively, the term can be empirically falsified in Schmückle's case.
\end{abstract}

How social histories are narrated depends on which concepts are employed and for what purpose. 'Western Marxism' is such a concept and is employed to map particular pioneering figures in particular periods of time in particular places, but also to critically situate Western Marxism in the theoretical framework that it creates and to which it belongs.

Curiously enough, Western Marxism is a negative term. It is something that is not 'Soviet Marxism.' In contradistinction to whatever is called 'Soviet' or Soviet Marxism in terms of political economy, ideology, philosophy or literature, Western Marxism rather is a protest against, or a critical attitude towards the ways in which the history of Marxism has developed. It is a reclamation of its own place. Western Marxism then is something more, or other, than a mere category of social historiography. Its ambitions go far beyond the standard tasks of any historical narrative: it attempts to reshape the narrative of the history of Marxism itself.

This ambition to become a genuine subject and object of its own historical narrative has a certain novelty. But how different is this from what it desperately tries to distinguish itself from - Soviet Marxism? Much of what is, or can be, said of Western Marxism with respect to its narrative ambitions also applies to its Soviet counterpart. They share a pattern in this regard. Is this because there actually is no clear-cut line between Western and Soviet Marxisms? The problem may have been misplaced from the very beginning, for it seemingly arises from an East-West binary. This binary is blurry because it requires further definitions of 'East,' 'West' and, of course, 'Marxism.' However, these terms are usually ill-defined, even though they have been employed for a long time and widely circulated by many historians of Marxism. 
Thus, we are told that these are the concepts to begin with if we are to attempt to grasp the motivating forces within the history of Marxism.

Western Marxism is not, and never claimed to be, immune to critique. Quite the contrary, it presupposes an examination of its own tools. Following this lead, the present article sees its task, perhaps paradoxically, in questioning whether and to what extent the very term Western Marxism applies to a group of German scholars of Karl Marx and Friedrich Engels in the Soviet Union, but more closely to one particular figure from that group: Karl Schmückle. ${ }^{1}$

Born in 1898 in south-western Germany, Schmückle was the son of a lumberjack, a student of Karl Korsch in Jena, a colleague of Georg Lukács in Moscow, a militant of the Communist Party of Germany (KPD) and later a member of the All-Union Communist Party of Bolsheviks (VKP(B)). He was a prominent Marxologist, a historian of European social utopias, a literary critic and novelist, and an editor of the first Marx-Engels-Gesamtausgabe $\left(\mathrm{MEGA}^{1}\right){ }^{2}$ Schmückle was politicized during the First World War, then joined the KPD and worked in different communist papers such as Rote Fahne and Die Internationale. He was also one of the participants of the Erste Marxistische Arbeitswoche, a 1923 seminar organized by Felix Weil, the co-founder of the Frankfurt Institute for Social Research. Aware of Schmückle's many talents, Weil recommended him to the MarxEngels Institute in Moscow when David Riazanov, the director of the Institute, was looking for German editors to work on his MEGA ${ }^{1}$ project. Schmückle worked at the Moscow Institute until Riazanov was charged with Menshevik conspiracy. The Institute was shut down in 1931, and Schmückle, along with many others, was dismissed. Until his arrest in 1937 for Trotskyist espionage, and execution in 1938, Schmückle contributed to certain Soviet-based German papers such as Deutsche Zentral-Zeitung and Internationale Literatur. ${ }^{3}$

Did Schmückle fit into the category of Western Marxism? I would argue that the way Western Marxism is identified and the biographical, geographical and theoretical patterns it provides run into controversy when it comes to Schmückle. The central issue in identifying Western Marxism has consisted thus far in detecting the figures who are either originally from, and reside in, or emigrated to the West. Therefore Marxists moving in opposite directions, from West to East, comprise something of a blind spot in this narrative. Moreover, what scholarly contributions they made in the Soviet Union, and how their achievements were echoed in the West, is out of the scope of Western Marxist historiography. One of the significant, and controversial, examples is perhaps the scholarly edition of Marx and Engels' works that caused a massive change in the ways Marx and Engels were read and interpreted in the East and West. Nevertheless, in Schmückle's case there are some other aspects that need to be taken into account. One of the core elements of Western Marxism is its alleged scientific-theoretical system or a world outlook open to non-Marxist sources. I will show that this perfectly applies to Schmückle's works on European intellectual history and literary criticism, which he wrote before and after he emigrated to Soviet Union, and even after he was dismissed from the Marx-Engels Institute.

In this article, I will first focus on how the term Western Marxism was coined and examine to what extent it applies to Schmückle. I will then go into some of Schmückle's own writings in order to portray a type of intellectual in the Soviet Union of the 1920s and 1930s. Some additional remarks on his trial and execution will also be helpful to understand the factual circumstances and the physical environment that might underlie 
his absence in the historiographies of Marxism. This study certainly challenges the Western Marxist narrative. My intention here, however, is not to bury the eponyms of Western Marxism but to use its ambivalences in a productive way. One might call this approach a fruitful paradox.

\section{What is Western Marxism?}

Western Marxism is commonly considered an intellectual current of 'Marxists who were politically independent of the Soviet Union.' Accordingly, they were 'not conforming to the official Soviet ideology,' and 'not regarding the social structures of the Soviet Union either as socialist, or as developing towards socialism.' 'Marxists,' on the other hand, are those whose main intellectual focus consists of "economic and social forces' of history, that is a 'specific series of successive social formations' based on a dialectical dynamic of class struggle. ${ }^{4}$ Furthermore, some biographical, geographic and theoretic traits are used in order to demarcate 'Western Marxism' as an integrated tradition.

Almost all of the Western Marxists had a middle-class background and were radicalized during the First World War. They were either natives or emigrants of Western Europe. Theoretically, they represented a 'structural divorce' from 'political practice.' Unlike the 'Classical Marxism' before the First World War that typically performed an inseparable political-intellectual function in political parties in Eastern and Western Europe, Western Marxism experienced a rupture between theory and praxis in a generational context after the First World War. ${ }^{5}$ A theoretical shift from politics and economy to philosophy, culture and literature is ascribed to Western Marxists in order to distinguish them from their Soviet counterpart. The first receptions of and massive reactions to the newly published early philosophical writings of Marx in 1920s and 1930s, so the argument goes, played a major role in its theoretical turn. ${ }^{6}$ But more importantly, the gulf between socialist theory and working-class practice, we are told, results from an 'institutionally widened and fixed ... bureaucratization of the USSR and of the Comintern under Stalin." If 'Soviet Marxists' 'finish on top,' 'write the histories,' 'hand out the medals' and had glorious victories on the stage of history, then 'Western Marxists' are those who are "silenced and defeated." "The success of Soviet Marxism contributed to, and often directed, the defeat of other Marxisms.' 9

Whether a dissident leftism of this sort can be called Marxism is not my topic here. ${ }^{10} \mathrm{I}$ am, rather, interested in the patterns that this narrative provides. It is argued that all the pioneering figures of Western Marxism have something in common. To name a few, Georg Lukács (1885-1971, b. Budapest), Karl Korsch (1886-1961, b. Todstedt, West Saxony), Antonio Gramsci (1891-1937, b. Ales, Sardinia), Walter Benjamin (1892-1940, b. Berlin), Max Horkheimer (1895-1973, b. Stuttgart), Herbert Marcuse (1898-1979, b. Berlin) are viewed as the first-generation Western Marxists. Lukács was the son of a banker, Korsch of a bank manager, Gramsci of a civil servant, Benjamin of an art dealer, Horkheimer of a textile manufacturer and Marcuse of a factory owner. Horkheimer was native to, and Lukács and Marcuse were trained in, south-west Germany. After Fascism came to power in West European countries, they were either exiled, imprisoned or killed. The first three figures, Lukács, Korsch and Gramsci, were politically radicalized shortly before, but mostly 
during the war, and became leaders of socialist organizations after that. This, however, is not the case for the last three figures (Benjamin, Horkheimer and Marcuse). They were either not involved in politics at all or they were politicized, if only for a short period of time.

As far as the criticism of the term is concerned, it suffers most significantly from geographic specialization because:

Marxism aspires in principle to be a universal science - no more amenable to merely national or continental ascriptions than any other objective cognition of reality. In this sense, the term 'Western' inevitably implies a limiting judgment. Lack of universality is an index of deficiency of truth. Western Marxism was necessarily less than Marxism to the extent that it was Western. Historical materialism can exercise its full powers only when it is free from parochialism, of any kind. It has yet to recover them. ${ }^{11}$

As an 'unfortunate detour from "classical" Marxism," ${ }^{12}$ it was 'fatally flawed by a loss of contact with a vital, activist working-class movement. ${ }^{13}$ Unlike Russia, the West witnessed unsuccessful attempts or even defeats of revolutionary struggles of the working class for political power. In addition, Soviet hegemony of mass working-class organizations in the East and West has constricted a lively development of a non-dogmatic sort of Marxism. As a result, 'Western Marxists' have 'faced a set of alternatives, all of which served to distort and displace Marxist theory.' ${ }^{14}$ They abandoned some basic concerns of classical Marxism such as the economic laws of capitalism, the theory of capitalist and socialist states and the question of the revolutionary strategy of the working class. This supposedly led them to turn their 'collective attention to philosophy and to the realm of culture. 15

Although the term clearly indicates quite mechanistically a geographic distribution of theoretical topics of a non-practical 'Marxism,' and tries to justify its Westernness by calling its pioneering figures 'authors from North America and Western Europe, ${ }^{16}$ the real intention, I suspect, is primarily to specify those Marxist or leftist social theorists critical of Soviet context, with a certain intellectual direction towards a progressive social, philosophical and political theory of culture and aesthetics. At least since Maurice Merleau-Ponty launched the term in the 1950s, it has intended to represent groups of critical theorists as part of the entire corpus of twentieth-century Marxisms. ${ }^{17}$ However defined, it is, as Göran Therborn stresses, a Nachkonstruktion or a post hoc construction. ${ }^{18}$ Theoretical innovations such as Lukács' theory of reification and aesthetics, Korsch's philosophical Marxism, Gramsci's concept of hegemony, Adorno and Horkheimer's understanding of liberation as a reconciliation with nature, Marcuse's recourse to Freudian psychoanalysis and utopian inspiration of liberation of nature in man, Benjamin's messianic socialism and Bloch's expressive utopianism are read by Perry Anderson as the key signatures of that construct. Gramsci was, after Lukács and Korsch, perhaps the last of its thinkers who directly broached the issue of class struggle, though not in the sense of a classical economic analysis of the capitalist mode of production. ${ }^{19}$ However, it was culture and art, rather than law and state, that engaged the major intellectual energies of Western Marxists. Lukács's life-long devotion to theory and history of the European novel, Adorno's works on music and contemporary culture, Benjamin's theoretical achievements as an art and literature critic among others belong to the same intellectual family. It is probably the spirit of this family that is nowadays called Western Marxism. ${ }^{20}$ 
Perhaps it would not be wrong to speak of a 'master text' of Western Marxism as well. I have in mind Marx's so-called Economic and Philosophic Manuscripts of 1844 that were quickly politicized and gave rise to the East-West binary. These texts, edited by Schmückle and later published by Adoratskii, were viewed by Marcuse as 'a crucial event in the history of Marxist studies.' They shed light on 'the origins and the original meaning of historical materialism and the entire theory of "scientific socialism".' It could even 'become necessary to revise the current interpretation of the later and more elaborate critique in the light of its origins. $^{21}$ For Marcello Musto, these lines imply a direct critique of Soviet Marxism and of its false view that was:

... put forward by exponents of the Second International and Soviet Communism that in Marx there was simply ... a transformation from a philosophical to an economic basis and that in its subsequent (economic) form philosophy had been overcome and 'finished' once and for all.

After the publication of the Manuscripts, it was no longer possible to think of Marxism as an 'essentially economic doctrine. "22 For Iring Fetscher, the very publication of the Manuscripts is ambiguous, for they 'centre so strongly on the liberation of man from every form of exploitation, domination and alienation, that a Soviet reader must have understood these comments as a criticism of his own situation under Stalinist domination. '23 Later, Adorno was to speak of a Soviet 'desire for rapid growth in production' and 'production for its own sake' that 'became the goal and prevented the attainment of the true goal of an unconfined freedom. ${ }^{24}$ Adorno goes so far as to claim that the similarity between capitalist West and socialist East is all too obvious. At least in the West, the capitalist reality and its utopian negation go hand in hand, though they go down a dead end. 'Today, criticism of utopias has degenerated into the stock inventory of [the capitalist] ideology, while the triumph of technical productivity deludes us into believing that utopia, which is irreconcilable with the relations of production, has nevertheless been made real.' The struggle between 'East and West,' however, makes 'the possible impossible. ${ }^{25}$

It is uncertain whether Schmückle could have predicted the pessimistic impact of the Manuscripts, but he clearly opposed the attempt to use this, or any other, text by Marx as a springboard to attack Soviet Marxism. Schmückle's 'East' is coloured by a Leninist optimism. And this optimism has, as I will discuss below, not only ideological but also literary dimensions. Starting from some formal patterns, my next step will be a reconsideration of Schmückle as a Western Marxist. I will argue that, at least in his case, the Western Marxist label can be empirically falsified.

\section{Was Schmückle a Western Marxist?}

Schmückle was close in terms of social class origin to Gramsci and of geographical origin to Horkheimer. He was politically and educationally closest to Korsch, and intellectually and professionally to Lukács. He was, like Korsch, a member of the KPD but, unlike Korsch, he was never expelled from the KPD. Like Marcuse, he was drafted into the German Army, and then assigned to a soldiers' council in 1918. He came to the Marx-Engels Institute long 
before Lukács and worked with him when editing Marx's famous Paris Manuscripts. In an interview from early 1960s, Lukács remembers that time in Moscow:

When I was in Moscow in 1930, R[i]azanov showed me the manuscripts which Marx had written in Paris in 1844. You can imagine my excitement: reading these manuscripts changed my whole relation to Marxism and transformed my philosophical outlook. A German scholar from the Soviet Union was working on the manuscripts, preparing them for publication. The mice had got at them, and there were many places in the manuscripts where the words had letters missing, or a word missing. Because of my philosophical knowledge, I worked with him ... ${ }^{26}$

This 'German scholar from the Soviet Union' was probably Schmückle. However, Lukács and Schmückle met back in 1923 during Erste Marxistische Arbeitswoche in Ilmenau, Thüringen, organized by Felix Weil and Richard Sorge, a Russian-German KPD militant. Karl Korsch, Friedrich Pollock and Karl Wittfogel also participated in the seminar. ${ }^{27}$

The dissertation thesis Schmückle wrote in Jena was a historical materialist analysis of social utopias, and printed shortly after Lukács's 1923 book History and Class Consciousness and probably before Korsch's Marxism and Philosophy. ${ }^{28}$ His talent in languages, expertise on early Marx and Engels, and loyal work in KPD's press organs were all positive references for his employment by the Institute in Moscow. But it is Lukács and Korsch, not Schmückle, who are viewed as 'the real originators, ${ }^{29}$ and their works as 'authentic events' 30 of Western Marxism. Why? One possibility is that Schmückle was only a historical footnote, an editor, a secondary figure. His scholarly articles were forgotten or lost in journals. Another possible reason is the distaste of Western Marxist narrative for the KPD, a close ally of the RKP(B) (Russian Communist Party of Bolsheviks) and the VKP(B) (All-Union Communist Party of Bolsheviks). A third reason might be his execution. I will argue that he was a victim of a Byzantine intrigue inside the Marx-Engels Institute. But before that, let me go into his journey to Moscow, and afterwards.

\section{MEGA $^{1}$ and Schmückle}

After the First World War, Schmückle started studying philosophy and theology in Tübingen and attended lectures of Heinrich Cunow, Gustav Mayer and Werner Sombart in Berlin and of Gerhard Kesler and Karl Korsch in Jena. He also worked as an editor and author for Arbeiter-Zeitung, Rote Fahne and Die Internationale. His dissertation thesis Logical Historical Elements of Utopia was dedicated to a systematic study of Marx and Engels' sources of utopian literature, including two generations of utopian writers from the seventeenth to nineteenth century such as More, Campanella and Morelly. Along with Karl Kautsky's book and articles on More's Utopia, Schmückle's study was one of the most comprehensive studies on the utopian sources of Marxism at that time.

Originally inspired by Marx's conception of utopia and probably provoked by Kautsky's economistic-reductionist understanding of it, Schmückle read older utopias as progressive reactions to social miseries and, to some extent, as justified fantasies 
about a better world. Implicitly, he seemed to affirm what Marx wrote of past utopias that they 'subordinate the whole movement to one of its elements,' narrate that single component with 'great sentimental rhetoric,' but finally wish away 'the necessities of the revolutionary class struggles. ${ }^{31}$ Most significant elements of utopia are the utopian state in More, the enlightened prince and wise ruler in Campanella or a social machinery in Morelly. ${ }^{32}$ Schmückle observed that late utopians like SaintSimon and Fourier tend to be more empirical and holistic, less atomist and reductionist. Conspicuously, Saint-Simon recognized labour as the material substance of all human capacities in the present industrializing society and finds in it the revolutionary power to eliminate social poverty. In Fourier, by contrast, the main parameter of the social dynamic was a dialectic of pain and happiness. Human passions and desires are the driving force of a society for a better future that are regularly disrupted or distorted by individual antagonisms. In a strikingly Hegelian fashion, Schmückle described Fourier's basic motive as a 'harmonic, natural contradiction.' As a result of social conflicts, natural contradictions turn into 'real contradiction[s].' The logical form of this transition is a 'mere negation of negation. ${ }^{33}$ Combined with Marx's materialism, historical dialectic teaches us, as Schmückle understood it, that an expanding penetration of new modes and relations of production results in an intensive class formation and conflict. Ultimately, this gives rise to social disharmonies and utopian reactions to them. The utopian point of view, Schmückle concluded, is less about explaining why things are the way they are than how they could be imagined and realized otherwise. ${ }^{34}$

Schmückle met Felix Weil, later the co-founder of the Frankfurt Institute for Social Research, at the First Marxist Study Week (1923). He would mention Schmückle's name to David Riazanov, the director of the Marx-Engels Institute in Moscow, who, with support of the Comintern and VKP(B), had launched his long-term project of publishing Marx and Engels' works.

After his return to Russia in 1917 from exile, Riazanov joined the Bolsheviks and played an important role in trade unions and other organizations, including founding and directing a state archive between 1918 and $1920 .{ }^{35}$ He was a full member of the Central Executive Committee of the Soviets until 1930. In 1918, he submitted an official plan to establish a socialist academy that was supposed to unite all Marxist scholars in the entire country. The central directorate of this academy included M. N. Pokrovskii, I. I. Skvortsov-Stepanov, A. V. Lunacharskii, A. A. Bogdanov, N. I. Bukharin and A. M. Deborin among others. ${ }^{36}$ In 1920, the Central Committee of the Russian Communist Party (Bolshevik) decided to establish a Marx-Engels Institute containing six divisions: scientific offices, library, archive, museum, publishing house and financial administration. ${ }^{37}$ After the Fifth World Congress of the Communist International in 1924, the idea of publishing the complete works of Marx, Engels and Lenin was strongly supported, and the Institute was finally assigned to start the prolonged MEGA ${ }^{1}$ project.

MEGA $^{1}$ was originally planned to be a 42 -volume project. It was divided into four sections. The first section was estimated to include 17 volumes containing all philosophical, economic (except for Capital), historical and political works by Marx and Engels. The second section included Capital and all the relevant economic materials to it. The third section was dedicated to correspondence between Marx and Engels and the fourth section to a complete index of names and topics. Contrary to the publication practices within the German Social Democratic circles that focused on arbitrary selections of single works such as Marx's Capital, Engels' Anti-Dühring or some of Marx and 
Engels' correspondences, Riazanov had a scholarly edition of Marx and Engels' works in mind that included everything written by Marx and Engels such as letters, notes, excerpts, finished and unfinished works. The project was designed to start with Marx and Engels' earliest writings. The editorial work required not only a profound knowledge of Marx and Engels' intellectual legacy and biography, but also a mastery of different languages and familiarity with Marx and Engels' earlier literary and philosophical sources. Candidates were expected not only to do the job, but also to fit into a certain political profile. In other words, they had to be editorially and intellectually qualified and politically reliable. Schmückle met both criteria. Weil's recommendation has been approved by the KPD leadership. Schmückle arrived in Moscow in 1925 and became a member of the Institute.

Schmückle edited the MEGA ${ }^{1}$ volumes of Marx and Engels' writings from the late 1830s until 1844 (volumes I/1.1 and I/2, published in 1927 and 1930, respectively) including Marx's dissertation thesis On the Difference between Democritean and Epicurean Philosophy and its seven preparatory notebooks, two poems from 1837, two articles on Martin Luther's religious morals and Prussian censorship, over 20 articles published in Rheinische Zeitung, one article on academic freedom that Bruno Bauer published in Deutsche Jahrbücher für Wissenschaft und Kunst, letters from Deutsch-Französische Jahrbücher, On the Jewish Question and Contribution to the Critique of Hegel's Philosophy of Right, Marx-Engels correspondence between 1844 and 1853 (volume III/3, published in 1929), and prepared the commentary volume I./1.2 (published in 1929). He also co-edited and contributed to the edition of Marx and Engels' The Holy Family and Marx's Economic-Philosophical Manuscripts (volume I/3, published in 1932), The German Ideology (volume I/5, published in 1932), and Marx-Engels correspondence 1868-1883 (volume III/4, published in 1931). Due to his removal from the Marx-Engels Institute in 1931, along with Riazanov and others, his name did not appear in the volumes published after $1930 .^{38}$

As for the content, form and purpose of MEGA ${ }^{1}$, there is at least one external factor worth mentioning: two previous standard editions of Marx and Engels' works. The first one was a four-volume collection of writings of Marx, Engels and Lassalle between 1841 and 1862 (Aus dem literarischen Nachlass von Karl Marx, Friedrich Engels und Ferdinand Lassalle) edited by Franz Mehring (1902; 1913), and a four-volume collection of Marx-Engels correspondence between 1844 and 1883 (Der Briefwechsel zwischen Friedrich Engels und Karl Marx 1844 bis 1883) edited by August Bebel and Eduard Bernstein (1913). Both editions suffered from arbitrary selections, deletions, omissions and correction of the textual material that had been openly attacked by Riazanov. For instance Mehring left out Marx's Contribution to the Critique of Hegel's Right and the chapter on Saint Marx in German Ideology for he did not find them significant enough to publish. ${ }^{39}$ On the other hand, the publishing company Dietz, with which Mehring was collaborating, was against reprinting texts that were already available on the market, such as Marx's articles in Rheinische Zeitung, or legally sensitive writings such as Marx's Hohenzollern General Plan of Reform, which could be seen as insulting government authorities. ${ }^{40}$ The same problems applied to Bernstein's edition. Bernstein omitted nearly 180 letters of Marx, Engels or other correspondents. Intimate and private letters were also left out. For example, Bernstein did not publish Engels' complaints to Marx about his conflict with his father, Marx's two references indicating a conflict with his mother, and material exposing Marx's poverty. ${ }^{41}$ Riazanov even compared Mehring's 
and Bernstein's approach to a music editor, deleting or correcting Beethoven's notes whenever he considers it necessary. ${ }^{42}$

With the German editorial censorship and arbitrary selections in mind, Riazanov made clear in his introduction to the $\mathrm{MEGA}^{1}$ volume I/1 that the ultimate goal of the critical complete edition of Marx and Engels' works (MEGA ${ }^{1}$ ) was to preserve and reproduce the entire textual record of Marx and Engels' writings. MEGA ${ }^{1}$ was also establishing an objective basis for further Marx-Engels research. ${ }^{43}$ Editorial introductions to the textual history and the index of references and sources of the recorded material would stimulate readers and researchers and enable them to gain access to Marx and Engels' entire work. ${ }^{44}$ Thus, the core of the edition was the edited text, not the supplementary volume or apparatus that reconstructed Marx and Engels' writing process and followed the evolution of the texts' individual and social histories. The main editorial concern was to produce versions of Marx and Engels' writings that were as authentic as possible. In providing a textual description of the genesis of published material and an explanation of personal and social-historical motives involved in the intents of the author(s), the editor was supposed to play the middleman between the author(s) and the reader or researcher. In other words, MEGA ${ }^{1}$ editors were supposed to reconstruct the process of Marx and Engels' theoretical achievements, on one side, and contribute to creating a more authentic, and politically more faithful and certainly not neutral image of Marx and Engels, on the other.

When preparing the MEGA $^{1}$ volume I/1, Karl Schmückle, along with other German editors Walter and Gertrud Biehahn, Georg Roeber, Walter Rohr, Hans Stein and Karl Schiller, commented in a letter on 25 October 1926 concerning the necessity of simultaneous publication of the edited text (volume I/1.1) and the commentary volume (volume I/1.2), 'for without these explanatory remarks the content of this volume [I/1.1] can, at most, only offer something for the narrowest circle of expert scientists. Without the commentary, only some of the purely theoretical parts will be of interest at best, while the historical achievement of Marx recorded in his contemporary political works will only extremely poorly emerge. ${ }^{45}$ In 1927, Riazanov published the volume MEGA ${ }^{1} \mathrm{I} / 1.1$ without the supplementary volume I/1.2 (which would be published in 1929). The first volume from the third section (volume III/1, MarxEngels correspondence 1844-1853, published in 1929), by contrast, already included an editorial guideline and its explanation in the introduction to the same volume. While some of the reviewers praised Riazanov for bringing to light the unknown and lost writings of Marx and Engels, others pointed out that the commentary was highly selective and arbitrary, and that it did not really clarify a majority of obscure or even ambiguous passages and expressions of Marx and Engels. The critical edition as such met, so the argument goes, the needs of only the scientific community and a small circle of experts. ${ }^{46}$

Part of the problem of Riazanov's editorial practice was that MEGA ${ }^{1}$ did not have any clear editorial principles according to which the editors could produce the copytexts. Most of the basic editorial rules such as orthography and punctuation were not standardized. The issue of how to structure each volume diachronically and synchronically was unclear. The apparatus was limited to textual critique and bibliographical explication without much information regarding the content and context of the edited text whatsoever. ${ }^{47}$ The editorial approach to the texts improved in the following years. In February 1932 the Institute held a consulting session that informed the MEGA ${ }^{9}$ 
editors about the standardized editorial guidelines of MEGA ${ }^{1}$ under the supervision of Adoratskii, Riazanov's successor. The session gave birth to an Instruction for Text Production, an Instruction on the Structure and Apparatus of the Volumes in the First Section of $M E G A^{1}$, a special instruction for the publication of Capital in the second section of $\mathrm{MEGA}^{1}$, and a special instruction for the MEGA ${ }^{1}$ volume I/7 (the articles from Neue Rheinische Zeitung). ${ }^{48}$ Due to his alleged involvement in the anti-Bolshevik conspiracy and removal from the Institute, Riazanov did not witness this development.

\section{Schmückle after MEGA ${ }^{1}$ : the utopian turn}

After Riazanov's dismissal from the directorship of the Institute and deportation to Saratov, ${ }^{49}$ Adoratskii, the new director of the Marx-Engels (Lenin) Institute, was assigned to organize a commission to examine the professional and political profiles of the 243 members of the Institute. Schmückle was considered to be 'useful in case of a strong leadership at the Institute,' while his wife Anne Bernfeld-Schmückle, who also worked at the Institute, was reported as being unreliable. The commission dismissed most of the Institute members. Schmückle and his wife were forced to leave their posts. ${ }^{50}$ After that, Schmückle worked for some German-language Soviet journals such as Deutsche Zentral-Zeitung between 1931 and 1934, and Internationale Literatur between 1934 and $1938 .^{51}$ In 1932, he became a member of the International Union of Revolutionary Writers (IVRS) and helped organize an antifascist front of (mostly but not only) German writers in and outside the Soviet Union.

As Fascism rose in Western Europe, Schmückle wrote a series of political literary essays including a review of Anna Seghers' novel The Road Through the February (1935), Story of the Golden Book: A Utopian Reportage (1935), Thomas Mann Against Fascism (1936), The Contemporary Don Quixote (1936) and Encounters With Don Quixote (1936). The main reason for Schmückle's turn to the concept of utopia seems to be the contemporary politicization of literary classics such as Thomas More's Utopia and Cervantes' Don Quixote. In his own short story 'The Contemporary Don Quixote,' Schmückle writes that in recent times Cervantes' novel was named a 'world book' and a 'monument of humanity' that mirrors the 'struggles and tendencies of our age.' Many believe to have found in it "practical virtues of a touchstone of the intellectual life in present time. ${ }^{52}$ With this vision of Cervantes in mind, Schmückle was at pains to respond to Jimenez Caballero, a Spanish Fascist leader, who attacked Cervantes' legacy and charged his book with Bolshevism, degeneration and perversion. ${ }^{53}$ The short fiction 'Story of the Golden Book,' written shortly before his essays on Cervantes, was motivated by the same idea. That is, the literary (and philosophical) classics are to be inherited and critically appropriated, which was an intellectual move directed against the total annihilation of human heritage fashioned by fascist leaders in Western Europe.

The plot of 'Story of the Golden Book' is an imaginary journey of Thomas More, who visits Moscow in 1935, interviews Soviet citizens about their lives under socialist rule and then heads to Kiev, Ukraine. Schmückle, as the narrator of the story, plays the role of a journalist who discovers the diary of his friend Jakob Luckert where Luckert documents More's journey in the Soviet Union. Luckert, we learn from the story, is none other than Raphael Hythlodaeus, a famous figure in More's utopia. When accompanying More in his time travel, Luckert (Hythlodaeus) gets killed by a 
Nazi officer's bullet and leaves his diary behind, which Schmückle the journalist discovers and uses to write this short story. ${ }^{54}$ What we know as Utopia today is supposedly the revised version that More prepared based on his observations in Western Europe and the Soviet Union. That he spends eight months in a German concentration camp before arriving in Moscow is one of his experiences of the brutality of Fascism. ${ }^{55}$ Moscow, by contrast, is what More calls 'Amaurotum' in his book, that is the capital of Utopia. ${ }^{56}$ More's Utopia finds all evil in gold, money and private property; evils that are to be repressed by the utopian laws. In fact, he is astonished by what he was told by a young communist, Nina Platonova, who tells him that they, the Soviet people, will abolish money when they build the world commune. ${ }^{57}$ All in all, More is portrayed as being convinced that the Soviet country seems to have arrived at some more humane life by abolishing private property and creating social equality. Yet More is too unfamiliar with this brave new world. Marx's critique of property, that is, the individual possession of collective means of production, is new to him. Kautsky's book on Utopia is now on his reading list. In the Soviet Union he finds an already realized utopia, a certain form of life and type of state that he was dreaming of and has written a book about.

\section{Schmückle's dystopian end: trial and execution}

As part of the larger struggle against the Trotskyist conspiracy, 18 writers and three Party officials as members of the German commission of Soviet Writers' Union including Alexander Barta, Hans Günther, Hugo Huppert and Georg Lukács were assigned by the Party to organize a series of closed Party sessions in September 1936 to reveal Trotskyists and Nazi spies in Soviet intellectual circles. The recently dismissed members of the former Marx-Engels Institute were under attack once again. Just weeks before the inspection session, Literaturnaia gazeta and Deutsche Zentral-Zeitung published anonymous attacks on Schmuckle, probably written by Hugo Huppert, an old enemy of Schmückle, charging Schmückle with Trotskyist betrayal. ${ }^{58}$

The closed Party sessions document that there was a pro- and anti-Schmückle camp inside the Institute. For some of his colleagues, Schmückle was a 'valuable worker' and 'one of a few Marxists we have in the Party. ${ }^{59}$ He never made an impression of a 'shameless' man who 'tricked and [still] tricks the Party. ${ }^{60}$ There is no single reason to believe that Schmückle even intended to betray the Party at all. ${ }^{61}$ For others, Schmückle was a 'counterrevolutionary' who avoided any open opposition against the Party. Schmückle's case was somewhat confusing, so the argument went, because he succeeded in hiding his real political intentions. ${ }^{62}$

Huppert, on the other hand, who knew Schmückle from the Marx-Engels Institute and Deutsche Zentral-Zeitung, was proud to have fought from the very beginning against that 'old confirmed opportunist' who 'obtained the trust of leading comrades by fraud. '63 Huppert even charged Schmückle's wife with 'Menshevik forgery. ${ }^{\text {,64 In }}$ October 1936, Schmückle was expelled from the Party (VKP(B)). In January 1937, he wrote to the KPD Central Committee member Wilhelm Pieck, and asked him desperately for guidance and support. Schmückle informed Pieck that he was accused of affiliating with some ultra-leftist circles between 1925 and 1927, and connections to certain anti-party groups in the 1930s. ${ }^{65}$ Schmückle was arrested in November 1937 anyway, and executed in March 1938. 
Huppert seems to have been the key figure in organising a massive campaign against Schmückle. Hence, he expressed his hostility towards Schmückle not only publicly but also privately. His diary from 1930/31 contains several notes, or attacks, full of ambition, jealousy, narcissism and hatred. He speaks of 'Schmückles' 66 (in plural) or a 'Schmückle-Clique' ${ }^{67}$ referring to the MEGA' editorial group under Riazanov's leadership. In March 1931, Huppert wrote that he 'received the task to prepare for publication volume 3 of the Gesamtausgabe (containing Marx's excerpts - from the Paris time; the 'philosophical-economic manuscripts'; 'The Holy Family'). The work bores me to tears. It is not my job. I submit myself to the discipline. ${ }^{68} \mathrm{He}$ also complained in one of his autobiographies that this editorial task left him almost no time for preparing for his lectures at the Institute for Foreign Languages. ${ }^{69}$ Elsewhere, by contrast, he called himself the 'editor of those world important writings that are named by us officially as Marx's Economic-Philosophical Manuscripts of the Year 1844,' and portrayed himself as the 'first, probably the only reliable, recognized decoder' of Marx's handwritings. ${ }^{70}$ All in all, Huppert managed to get rid of Schmückle and became his successor, but he too was arrested in March 1938 and stayed in prison for over a year for his alleged affiliation with anti-Party groups, a charge which Huppert himself had directed against Schmückle. ${ }^{71}$

\section{Schmückle: reader, editor and utopian}

That Schmückle fell victim to what the Western Marxist narrative calls 'Soviet Marxism' might suffice for some to reaffirm the idea that if the counterpart of Western Marxism consists of a history of victories and heroes, then Schmückle, in this case, certainly belongs to the camp of the 'defeated.' According to the aforementioned patterns of Western Marxism, this victimology is of a biographical and a geographical nature. It is only the theoretical pattern upon which Western Marxism so strongly relies and which also makes it so difficult to add Schmückle's name to the long list of Western Marxists. I am not aware of any trace of a 'structural divorce of philosophical theory from political theory' in Schmückle's life, except his execution. The attempt to categorize Schmückle, or anyone else, according to the golden patterns of Western Marxism is puzzling in this regard. I will return to this issue below when I speak of Schmückle as a utopian. My problem with Western Marxism is that it is unhelpful to understand Schmückle as an intellectual figure. It is not helpful because the devices it employs serve as an 'either-Western-or-Soviet-Marxist' template as if this is all that matters. I argue that this kind of approach rather encapsulates the question of who or what Schmückle is. We can do justice to a historically significant intellectual by considering his intellectual qualities. For this reason I prefer to take Schmückle as a professional Marxist reader, a Marxist editor and a utopian.

In his 1933 article, 'The Young Marx and Bourgeoisie Society,' Schmückle was involved in a quarrel around the political identity of the so-called young Marx. The article was planned to be a response to several contemporary Marxist interpreters such as Otto Bauer, Arthur Rosenberg, Siegfried Landshut, Jacob Mayer and Hendrik de Man. It was Bauer, Schmückle writes, who aimed to 'stamp the revolutionary young Marx as an egregious liberal opportunist.' With his 'ignorant' and 'anti-Bolshevik' spirit, Rosenberg joined the choir; young Marx, Rosenberg claimed, was 'bourgeois - 
not a proletarian, not a communist - revolutionary.' In their 'philologically completely nugatory' edition of Marx's Early Works, Landshut and Mayer managed to transform young Marx 'into an idealist cleric, into a preacher of the "moral idea".' It is the 'hatred against Leninism' that led 'Social Democratic spokesmen' to transform Marx into a 'veritable Neo-Hegelian':

The sharper, the more shameless and clumsy these Social Democrat agents of reactionary bourgeoisie emerge against Leninism, the coarser and the more barbaric they falsify the teaching of Marx and Engels. This is the inevitable consequence from the practical and political role which the party of these gentlemen plays in the class struggles of the present age. ${ }^{72}$

The intolerance Schmückle displays against the readings of Marx by those Social Democrats is not simply an intolerance of silly interpretations of Marx's texts. Those (mis)readings, rather, testify for Schmückle that there is no such thing as an innocent reading of Marx; they all mirror, and are a product of, certain political convictions. The real issue seems to be that two opposite interpretations of Marx claim authority for a certain, in fact singular, type of reading of Marx's texts, a reading which serves particular political purposes. In other words, the debate clusters around the issue of who will canonize Marx's texts to what end. It is beyond doubt that one of the ultimate goals of MEGA $^{1}$ was paradoxically to shift the authority of the meaning of Marx and Engels' texts to some extent away from Marx and Engels to a politically committed readership of a certain type. Schmückle, like many others of his generation, was simply at pains to make readers read Marx according to what the textual material has been decreed to mean. What matters, and what distinguishes a Leninist reading of Marx from a Social Democratic one, is how Marx and Engels' texts should function in the political context and how they affect the expectations of and create a politically committed community of readers. It is uncertain whether Schmückle believed that his Leninist reading of Marx enabled readers to follow their own path in order to understand Marx, or that they needed an instructor to guide them. This problem brings us to Schmückle the editor.

Schmückle, like Riazanov and Adoratskii, seemed to be aware that the MEGA ${ }^{1}$ editor was responsible for reproducing a text that reflected what Marx and Engels meant in a text and what particular meanings their texts had for the authors and their readers, respectively. Common sense suggests that an author's self-understanding and world view is the measure of all subsequent interpretations. However, the public debates Schmückle contributed to as well as the editorial practice he was involved in runs into a dilemma that the editor was in charge of not only reflecting the process of composition and social-political context of the works of Marx and Engels; he was also acting on behalf of Marx and Engels as if he was the authors' partner. In a way, Schmückle the editor, even after his dismissal from the Marx-Engels Institute, seems to have seen his life-long task in reading and approving the texts in the interest of other readers. That interest, however, was a political one which was fed by the present texts at hand and by the debates that clustered around them. If Schmückle downplayed the Social Democrat editions of Marx and Engels' works, then the main reason for that charge was not simply the philological inaccuracy or editorial insufficiency of the editors but their anti-Leninist functioning of Marx and Engels' texts. An 
edition of a text determines how that text is read. It is therefore not surprising to see that for Schmückle the task of creating a Leninist readership necessarily depended on which edition was read, how the edition was structured and in fact who were the editors.

Along with Schmückle's reading and editing of Marx there is another textual practice to be mentioned: his utopian writing. What some Western Marxists have written about utopianism and its relation to politics seems to offer, at a first glance, a plausible account of Schmückle's turn to utopia in his last and most turbulent years. It is argued that utopias or utopian writings are born at 'moments of the suspension of politics - if suspended in the sense of the legendary sword.' They retain 'at root a stubborn negativity, an emblem of what, despite everything, we cannot grasp or imagine, and which the characteristic oscillations and oppositions within the utopian repertoire bespeak." ${ }^{73}$ The utopian moment is the "calm before the storm, the stillness at the centre of the hurricane.' If 'some of the most extreme utopianisms emerge from the very centre of the revolutionary upheaval itself, "74 'when the ruling elite is palpably uncertain of itself and full of divisions and self-doubts, ${ }^{, 75}$ and when the distance between the malleable reality and the unchangeable system 'opens up a moment of ideational and utopian-creative free play in the mind itself or in the political imagination, ${ }^{76}$ is there then any choice left for us other than finding an upheaval in Schmückle's utopian turn? Disappointingly for the Western Marxist narrative, the addressee of that rebellion, if any, is not Soviet Marxism but Nazi Fascism. This, however, does not mean that there is nothing critical, for example, in Schmückle's story of More's journey to the Soviet Union.

For Schmückle, neither Marx nor More was of an antiquarian interest. The sort of reading he offered regarding these figures did not insist upon knowing their past in their own terms and for their own sake. If his reading of the historical and political past was done for contemporary purposes, then we might say that Schmückle repeatedly came back, or never left, the terrain of temporality. That is, the way he looked at past historical figures was a product of his concept of time. In other words, it is the relationship of political present to the historical past which is at issue. In 'Story of the Golden Book,' we witness that More's time travel registers his fantasies about the future which is Schmückle's present. Schmückle makes More experience a future shock, on one side, and he defamiliarizes his Soviet readers' experience of their present time, on the other. Given the political climate in the 1930s, we can say that either More's utopia came to an end for it became real in the Soviet Union, or Schmückle simply dramatized contradictions of Soviet self-perceptions on a deeper level of the utopian plot. This being said, I argue that Schmückle's utopian practice is hardly an 'ideological critique of the dominant [Soviet] ideology. ${ }^{, 77}$ By giving a voice to the past, however, that utopian narrative holds a mirror to its readers, or brings them to a 'mirror stage,' if you like, to make them recognize their present in the reflection of the past. This is something one might call critical, though not in the sense of a critique of a political ideology but of a political-historical narrative.

In drawing attention to Schmückle's case, I do not intend to offer a complete account or an exhaustive description of every figure relevant to his story. I do not pretend to examine the Western Marxist narrative from an Archimedean point of view by pointing at rights and wrongs of its historiographic implications. Mine is, rather, an 'ironic' attempt in cultivating a methodological awareness of the devices 
Western Marxism employs. ${ }^{78}$ Part of what I take as a problem is the self-confidence of Western Marxist historiography in servicing long lists of names representing its founders. Besides that, there is of course the claim of completeness and fullness of the history of Western Marxism in the hands of Western Marxists themselves. Schmückle's exceptional case is representative in the way that it does not promise potentially anything that can be easily fitted, or even assimilated, into that attempt. This, in turn, explains why someone like Schmückle has not been viewed as someone significant, because historically significant figures or events are those that can be integrated into a historical plot as designed by those who write the histories. What Western Marxism could tell us at best is that Schmückle was a Westerner, a Marxist, but hardly a Western Marxist.

\section{Notes}

1. Rokitianskii and Miuller, Krasnyi dissident, 68.

2. MEGA $^{1}$ or the first MEGA designates the project of the critical-historical edition of Marx and Engels' collected works that was launched in the 1920s and terminated in the 1930s. After a long break, Soviet and East German scholars decided in the 1970 s to take up the task to critically revise the previous editorial achievements and complete the historical critical edition. This later edition is called MEGA ${ }^{2}$.

3. Müller, 'Der 'Fall”' Schmückle', 76; Röhr, 'Einleitung', III.

4. van der Linden, Western Marxism and the Soviet Union, 4.

5. Anderson, Considerations on Western Marxism, 29.

6. Anderson, Considerations on Western Marxism, 50.

7. Anderson, Considerations on Western Marxism, 92.

8. Jacoby, Dialectic of Defeat, 2.

9. Jacoby, Dialectic of Defeat, 4. Exceptionally, Therborn refuses to mark Western Marxism by 'defeat': 'Not only was this obviously untrue of its founding moment, but Anderson's characterization now appears to take too narrow or specialist an angle. Rather, all the members of his list became Marxists because they regarded the October Revolution as a decisive, world-historical event.' See Therborn, From Marxism to Post-Marxism?, 91.

10. For charges against Western Marxist historiography see Arato and Piccone, 'Rethinking Western Marxism'; Fracchia, 'The Philosophical Leninism and Eastern "Western Marxism" of Georg Lukács'; Piccone, 'Perry Anderson, Considerations on Western Marxism'; Wolff, 'Western Marxism'.

11. Anderson, Considerations on Western Marxism, 94.

12. Jacoby, Dialectic of Defeat, 7.

13. Wolff, Western Marxism, 57.

14. Wolff, Western Marxism, 57.

15. Wolff, Western Marxism, 59.

16. van der Linden, Western Marxism and the Soviet Union, 5.

17. Merleau-Ponty, Adventures of the Dialectic, 30-58; Therborn, From Marxism to PostMarxism?, 83.

18. Therborn, From Marxism to Post-Marxism?, 87.

19. Anderson, Considerations on Western Marxism, 75.

20. Anderson, Considerations on Western Marxism, 76.

21. Marcuse, 'The Foundation of Historical Materialism. [1932]', 3. 
22. Musto, "The "Young Marx" Myth in Interpretations of the Economic-Philosophic Manuscripts of 1844', 243.

23. Fetscher, Marx and Marxism, 314.

24. Adorno, 'Late Capitalism or Industrial Society?', 122.

25. Adorno, 'Late Capitalism or Industrial Society?', 118.

26. Lukács, 'Lukács on His Life and Work', 56-57.

27. Hecker, 'Erfolgreiche Kooperation', 17-18.

28. Schmückle, 'Logisch-Historische Elemente der Utopie', 81.

29. Anderson, Considerations on Western Marxism, 29.

30. Žižek, 'Postface: Georg Lukács as the Philosopher of Leninism', 151.

31. Marx, 'Die Klassenkämpfe in Frankreich 1848 bis 1850', 89.

32. Schmückle, 'Logisch-Historische Elemente der Utopie', 28, 37.

33. Schmückle, 'Logisch-Historische Elemente der Utopie', 40, 48.

34. Schmückle, 'Logisch-Historische Elemente der Utopie', 32.

35. Rokitianskii and Miuller, Krasnyi Dissident, 58.

36. Rokitjanskij, 'Das tragische Schicksal von David Borisovic Rjazanov', 4.

37. Schiller, 'Das Marx-Engels-Institut in Moskau', 420.

38. Röhr, 'Einleitung', XXIII.

39. Rjasanow, 'Vorwort zur MEGA 1927', 1100-1101.

40. Rjasanow, 'Vorwort zur MEGA 1927', 1101.

41. For a more precise description of the differences between German and Soviet editions see Zhao, 'The Historical Birth of the First Historical-Critical Edition of Marx-EngelsGesamtausgabe', 15, 22-23.

42. Rjasanow, 'Vorwort zur MEGA 1927', 1103.

43. Rjasanow, 'Vorwort zur MEGA 1927', 1110.

44. Rjasanow, 'Vorwort zur MEGA 1927', 1096.

45. Mitteilung an Rjazanov, Internationaal Instituut voor Sociale Geschiedenis Amsterdam (IISG), Hans Stein Nachlaß, Marx-Engels-Studien, Akte 559/9 (Entwurf), quoted from Hecker, 'Rjazanovs Editionsprinzipien der ersten MEGA', 15; also see Zhao, 'The Historical Birth of the First Historical-Critical Edition of Marx-Engels-Gesamtausgabe', 17.

46. Kautsky, 'Die Werke von Marx und Engels', 175; Borkenau, 'Marx-Engels-Gesamtausgabe', 489; Anonymous, 'Der Briefwechsel zwischen Marx und Engels 18441853', 151; Kautsky, 'Die Marx-Engels-Gesamtausgabe', 262.

47. Hecker, 'Rjazanovs Editionsprinzipien der ersten MEGA', 21.

48. Hecker, 'Rjazanovs Editionsprinzipien der ersten MEGA', 23-24.

49. Rokitianskii and Miuller, Krasnyi dissident, 119; Burkhard, 'D. B. Riazanov and the Marx-Engels Institute', 46.

50. Röhr, 'Einleitung', XL-XLI.

51. Röhr, 'Einleitung', XLV.

52. Schmückle, 'Der aktuelle Don Quijote', 280.

53. Schmückle, 'Der aktuelle Don Quijote', 281.

54. Schmückle, 'Geschichte vom goldenen Buch', 266-267.

55. Schmückle, 'Geschichte vom goldenen Buch', 268.

56. Schmückle, 'Geschichte vom goldenen Buch', 271.

57. Schmückle, 'Geschichte vom goldenen Buch', 272.

58. Röhr, 'Einleitung', LXXI. 
59. 'Sitzung der deutschen Schriftsteller am 5. 9. 1936', as reproduced in Müller, Georg Lukács/Johannes R. Becher/Friedrich Wolf u.a., 128.

60. 'Sitzung der deutschen Schriftsteller am 5. 9. 1936', as reproduced in Müller, Georg Lukács/Johannes R. Becher/Friedrich Wolf u.a., 129.

61. 'Sitzung der deutschen Schriftsteller am 7. 9. 1936', as reproduced in Müller, Georg Lukács/Johannes R. Becher/Friedrich Wolf u.a., 269; 'Sitzung der deutschen Schriftsteller am 8. 9. 1936', as reproduced in Müller, Georg Lukács/Johannes R. Becher/Friedrich Wolf u.a., 452.

62. 'Sitzung der deutschen Schriftsteller am 5. 9. 1936', as reproduced in Müller, Georg Lukács/Johannes R. Becher/Friedrich Wolf u.a., 193.

63. 'Sitzung der deutschen Schriftsteller am 5. 9. 1936', as reproduced in Müller, Georg Lukács/Johannes R. Becher/Friedrich Wolf u.a., 204 and 208.

64. 'Sitzung der deutschen Schriftsteller am 5. 9. 1936', as reproduced in Müller, Georg Lukács/Johannes R. Becher/Friedrich Wolf u.a., 145.

65. Müller, 'Der "Fall” Schmückle', 77.

66. Huppert, 'Winter 1930/31', as reproduced in Huppert, 'Aus den Tagebuchaufzeichnungen 1930/1931', 355.

67. Huppert, '7. März [1931]', as reproduced in Huppert 'Aus den Tagebuchaufzeichnungen 1930/1931', 364.

68. Huppert, '11. März [1931]', as reproduced in Huppert 'Aus den Tagebuchaufzeichnungen 1930/1931', 366-367.

69. Huppert, Einmal Moskau und zurück, 133.

70. Huppert, Wanduhr mit Vordergrund, quoted from Müller, "'Das große Reinemachen" 1931', 351.

71. Stammberger and Peschke, Gut angekommen - Moskau, 141 and 155.

72. Schmückle, Der junge Marx und die bürgerliche Gesellschaft, 150-151.

73. Anderson, The River of Time, 67-68.

74. Jameson, The Politics of Utopia, 44.

75. Jameson, The Politics of Utopia, 45.

76. Jameson, The Politics of Utopia, 45-46.

77. Marin, Utopics, XIV.

78. White, Metahistory, 34; Callinicos, Theories and Narratives, 52.

\section{Disclosure statement}

No potential conflict of interest was reported by the author.

\section{Notes on contributor}

Kaan Kangal is an assistant professor at the Center for Studies of Marxist Social Theory at Nanjing University. His research interests are Marx-Engels research, the theoretical and editorial history of Marx and Engels' works and the history of German, Soviet and Chinese Marxist philosophy. Address: Center for Studies of Marxist Social Theory, Nanjing University, Xianlin Campus, Qixia District, 38 Nanjing, Jiangsu, 210046, Peoples Republic of China. [email: kaankangal@gmail.com] 


\section{References}

Adorno, Theodor W. 'Late Capitalism or Industrial Society? The Fundamental Question of the Present Structure of Society'. In Can One Live after Auschwitz? edited by Rolf Tiedemann, 111-125. California: Stanford University Press, 2003.

Anderson, Perry. Considerations on Western Marxism. London - New York: Verso, 1989.

—. 'The River of Time'. New Left Review 26 (March-April 2004): 67-77.

Anonymous. 'Der Briefwechsel zwischen Marx und Engels 1844-1853'. Unter dem Banner des Marxismus I (1930): 148-151.

Arato, Andrew and Paul Piccone. 'Rethinking Western Marxism: Reply to Martin Jay'. Telos 32 (June 1977): 167-174.

Borkenau, Franz. 'Marx-Engels-Gesamtausgabe'. In Archiv für die Geschichte des Sozialismus und der Arbeiterbewegung XIV, edited by Carl Grünberg, 485-489. Leipzig: Verlag von C. L. Hirschfeld, 1929.

Burkhard, Bud. 'D. B. Rjazanov and the Marx-Engels Institute: Notes toward Further Research'. Studies in Soviet Thought 30, no. 1 (July 1985): 39-54.

Callinicos, Alex. Theories and Narratives. Reflections on the Philosophy of History. Cambridge: Polity Press, 2007.

Fetscher, Iring. Marx and Marxism. New York: Herder and Herder, 1971.

Fracchia, Joseph. "The Philosophical Leninism and East "Western Marxism" of Georg Lukács'. Historical Materialism 21, no. 1 (2013): 69-93.

Hecker, Rolf. 'Erfolgreiche Kooperation: Das Frankfurter Institut für Sozialforschung und das Moskauer Marx-Engels-Institut (1924-1928)'. In Beiträge zur Marx-Engels Forschung Neue Folge. Sonderband 2. Erfolgreiche Kooperation: Das Frankfurter Institut für Sozialforschung und das Moskauer Marx-Engels-Institut (1924-1928), edited by Carl-Erich Vollgraf, et al., 9-118. Berlin: Argument, 2000.

_. 'Rjazanov's Editionsprinzipien der ersten MEGA'. In Beiträge zur Marx-Engels-Forschung Neue Folge. Sonderband 1. David Borisovič Rjazanov und die erste MEGA, edited by Carl-Erich Vollgraf, et al., 7-27. Berlin: Argument, 1997.

Huppert, Hugo. 'Aus den Tagebuchaufzeichnungen 1930/1931'. In Beiträge zur Marx-EngelsForschung Neue Folge. Sonderband 3. Stalinismus und das Ende der ersten Marx-Engels-Gesamtausgabe (1931-1941), edited by Carl-Erich Vollgraf, et al., 354-370. Berlin: Argument, 2001.

-. Einmal Moskau und zurück. Stationen meines Lebens. Halle-Leibzig: Mitteldeutscher Verlag, 1987.

Jacoby, Russell. Dialectic of Defeat. Contours of Western Marxism. Cambridge: Cambridge University Press, 2002.

Jameson, Fredrich. 'The Politics of Utopia'. New Left Review 25 (January-February 2004): 35-54.

Kautsky, Benedikt. 'Die Marx-Engels-Gesamtausgabe'. Die Gesellschaft 7 (1930): 260-270.

—. 'Die Werke von Marx und Engels'. Die Gesellschaft 5 (1928): 174-180.

Lukács, Georg. 'Lukács on His Life and Work'. New Left Review I, no. 68 (July-August 1971): 49-58.

Marcuse, Herbert. 'The Foundation of Historical Materialism. [1932]'. In Studies in Critical Philosophy, edited by Herbert Marcuse, 1-48. Boston: Beacon Press, 1973.

Marin, Louis. Utopics: The Semiological Play of Textual Spaces. New York: Humanity Books, 1990.

Marx, Karl. 'Die Klassenkämpfe in Frankreich 1848 bis 1850'. In Marx-Engels Werke, vol. 7, 9-107. Berlin: Dietz, 1960. 
Merleau-Ponty, Maurice. Adventures of the Dialectic. Evanston: Northwestern University Press, 1973.

Müller, Reinhard. “"Das große Reinemachen” 1931. Die "Säuberung” des Marx-Engels-Instituts im Moskauer Tagebuch Hugo Hupperts'. In Beiträge zur Marx-Engels-Forschung Neue Folge. Sonderband 3. Stalinismus und das Ende der ersten Marx-Engels-Gesamtausgabe (1931-1941), edited by Carl-Erich Vollgraf, et al., 347-353. Berlin: Argument, 2001.

Müller, Reinhard. 'Der “Fall”'Schmückle'. In Georg Lukács/Johannes R. Becher/Friedrich Wolf u.a. Die Säuberung. Moskau 1936: Stenogramm einer geschlossenen Parteiversammlung, edited by Reinhard Müller, 76-79. Hamburg: Rowohlt, 1991.

Musto, Marcello. 'The "Young Marx" Myth in Interpretations of the Economic-Philosophic Manuscripts of 1844'. Critique Journal of Socialist Theory 43, no. 2 (2015): 233-260.

Piccone, Paul. 'Perry Anderson, Considerations on Western Marxism ... Sebastiano Timpanaro, On Materialism ...'. Telos 30 (December 1976): 213-216.

Rjasanow, David Borisowitsch. 'Vorwort zur MEGA 1927'. UTOPIE kreativ H. 206 (Dezember 2007): 1095-1011.

Röhr, Werner. 'Einleitung'. In Karl Schmückle. Begegnungen mit Don Quijote. Ausgewählte Schriften, edited by Werner Röhr, I-LXXVIII. Berlin: Argument/Inkrit, 2014.

Rokitianskii, Iakov and Reinkhard Miuller, Krasnyi dissident. Akademik Riazanov - opponent Lenina, zhertva Stalina. Biograficheskii ocherk. Dokumenty. Moscow: Academia, 1996.

Rokitjanskij, Jakov. 'Das tragische Schicksal von David Borisovic Rjazanov'. In Beiträge zur Marx-Engels-Forschung Neue Folge 1993. Marx-Engels-Forschung im historischen Spannungsfeld, edited by Carl-Erich Vollgraf, et al., 3-16. Berlin: Argument, 1993.

Schiller, Franz. 'Das Marx-Engels-Institut in Moskau'. In Archiv für die Geschichte des Sozialismus und der Arbeiterbewegung XV, edited by Carl Grünberg, 416-435. Leipzig: Verlag von C. L. Hirschfeld, 1930.

Schmückle, Karl. 'Der aktuelle Don Quichote'. In Karl Schmückle. Begegnungen mit Don Quijote. Ausgewählte Schriften, edited by Werner Röhr, 280-300. Berlin: Argument/Inkrit, 2014.

Schmückle, Karl. 'Der junge Marx und die bürgerliche Gesellschaft'. In Karl Schmückle. Begegnungen mit Don Quijote. Ausgewählte Schriften, edited by Werner Röhr, 149197. Berlin: Argument/Inkrit, 2014.

. 'Geschichte vom Goldenen Buch. Eine utopische Reportage'. In Karl Schmückle. Begegnungen mit Don Quijote. Ausgewählte Schriften, edited by Werner Röhr, 265274. Berlin: Argument/Inkrit, 2014.

—. 'Logisch-historische Elemente der Utopie'. In Karl Schmückle. Begegnungen mit Don Quijote. Ausgewählte Schriften, edited by Werner Röhr, 3-83. Berlin: Argument/Inkrit, 2014.

Stammberger, Gabriele and Michael Peschke. Gut angekommen - Moskau. Das Exil der Gabriele Stammberger 1932-1954. Erinnerungen und Dokumente. Berlin: BasisDruck, 1999.

Therborn, Göran. From Marxism to Post-Marxism? London - New York: Verso, 2008.

van der Linden, Marcel. Western Marxism and the Soviet Union. A Survey of Critical Theories and Debates Since 1917. Leiden - Boston: Brill, 2007.

White, Hayden. Metahistory. The Historical Imagination in Nineteenth-Century Europe. Baltimore \& London: The John Hopkins University Press, 1975.

Wolff, Richard D. 'Western Marxism’. Monthly Review 30, no. 4 (September 1978): 55-64.

Zhao, Yulan. 'The Historical Birth of the First Historical-Critical Edition of Marx-EngelsGesamtausgabe. Part 3'. Critique: Journal of Socialist Theory 42, no. 1 (2014): 11-24.

Žižek, Slavoj. 'Postface: Georg Lukács as the Philosopher of Leninism'. In Georg Lukács: A Defense of History and Class Consciousness: Tailism and the Dialectic, 151-182. London: Verso, 2000. 